\title{
A single bio-energetics growth and reproduction model for the oyster Crassostrea gigas in six Atlantic ecosystems
}

\author{
M. Alunno-Bruscia ${ }^{a * *}$, Y. Bourlès ${ }^{a}$, D. Maurer ${ }^{b}$, S. Robert ${ }^{c}$, J. Mazurié $^{d}$, A. Gangnery ${ }^{e}$, \\ P. Goulletquer ${ }^{f}$ and S. Pouvreau ${ }^{a}$ \\ a Ifremer RBE-PFOM-PI, 11 Presqu'île du Vivier, 29840 Argenton-en-Landunvez, France \\ ${ }^{b}$ Ifremer LERA, Quai du Commandant Silhouette, 33120 Arcachon, France \\ ${ }^{c}$ Ifremer LERPC, Avenue de Mus de loup, 17390 La Tremblade, France \\ d Ifremer LERMPL, BP 86, 56470 La Trinité sur Mer, France \\ e Ifremer LERN, Avenue du Général de Gaulle, BP 32, 14520 Port en Bessin, France \\ ${ }^{\mathrm{f}}$ Ifremer Nantes, rue de I'lle d'Yeu, BP 21105, 44311 Nantes Cedex 03, France \\ *: Corresponding author : Marianne Alunno-Bruscia, email address : marianne.alunno.bruscia@ifremer.fr
}

\begin{abstract}
:
Many studies based on bioenergetics growth models have investigated the effects of environmental factors on oyster (Crassostrea gigas) growth and physiology. However, most of these models are site-specific and cannot be applied to other culture sites without the re-estimation of parameters or re-formulation of some processes. We aimed to develop a gen eric growth model suitable for application in contrasting environments, with a constant set of parameters. We tested the oyster-DEB model (Bourlès et al. 2009) for the stimulation of $C$. gigas growth in different cohorts (spats and adults) at major shellfish culture sites in France, in several years: Arcachon (1993-1994); Marennes-Oléron (2007); Quiberon (1999, 2000, 2001); Rade de B rest (2008); Baie du Mont-Saint-Michel (2003); Baie-des-Veys (2002). These different ecosystems offer a wide range of values for the two forcing variables of the model: water temperature (range: $6-24^{\circ} \mathrm{C}$ ) and phytoplankton concentration (annual average: $110-700 \times 10^{3}$ cell. $I^{-1}$ ). The validation data (dry flesh mass of $C$. gigas) were obtained from various growth surveys carried out by IFREMER. The oyster-DEB model simulated the oyster growth dynamics of both spat and adult stages of C. gigas accurately over time at the various culture sites. The model captures: $i$ ) the active spring growth; $i i)$ the timing and amplitude of spawning events; and iii) the lean periods (i.e. loss of dry flesh mass) in autumn and winter. The half-saturation coefficient $X_{k}$ is the only model parameter that varied between sites and years. This environment-specific coefficient reflects variability in the food of the oysters: quantitative and qualitative effects of the inorganic material and of the phytoplankton species on the feeding response of $C$. gigas. With a single set of parameters (other than for $X_{k}$ ), this is thus the first bio-energetic growth model for C. gigas robust enough and of a sufficiently generic nature for the accurate simulation of oyster growth in different Atlantic ecosystems.
\end{abstract}

\section{Highlights}

A generic growth model of the oyster Crassostrea gigas that is suitable for a generic application, i.e. with a constant set of parameters, in contrasting Atlantic environments and for different cohorts (spats and adults) was developed. The resulting oyster-DEB model simulated the oyster growth dynamics of both spat and adult stages of $C$. gigas accurately over time at the various culture sites. The model captures: $i$ ) the active spring growth; ii) the timing and amplitude of spawning events; and iii) the loss of dry flesh mass in autumn and winter. The half-saturation coefficient $X_{k}$ is the only model parameter that varied between sites and years. This environment-specific coefficient reflects variability in the food of the oysters.

Keywords: DEB theory; modelling; bivalves; Crassostrea gigas; phytoplankton; temperature effect; coastal environment. 


\section{Introduction}

The Pacific oyster Crassostera gigas is a key worldwide species in natur al marine ecosystems and marine aquaculture, and is on e of the best known non -indigenous animals living on the coasts of north-western Europe (Troost 2010). C. gigas was introd uced into Europe by and for human activities (shellfish culture) in the early $1970 \mathrm{~s}$. It is typically an invasive species: it has managed to establish itself successfully in contrasting environmental conditions, inducing many changes in the ecosystems in which it implants itself due to its considerable filtration capacity and sediment biodeposition and its ability to form extensive reef structures (Troost 2010). In France, it is also a key economic species in the shellfish market, with an annual production of $120,000 \mathrm{t}$, worth about $€ 270$ million per year (Buestel et al. 2009). This importance of the Pacific oyster in both natural and production syst ems has stimulated considerable recent interest in the factors underlying its gro wth and reproduction performances, particularly in the eco-physiology and bioenergetics of $C$. gigas.

The physiological processes and energetics of marine bivalves in response to environmental fluctuations can be described by e nergetic budget models, which have been e xtensively used for shellfish species in aquaculture (e.g. Héral, 1993; Dowd, 1997; Bacher et al., 1998; Grant et al., 2003; Duarte et al. 2010). Many of the energetic models for bivalves are net production models (e.g. Ross and Nisbet, 1990; Raillard et al., 1993; Smaal and Widdows, 1994; Barillé et al., 1997; Campbell and Newell, 1998; Scholten and Smaal, 1998; Ren and Ross, 2001) based on the Scope for Growth (SFG) concept (Bayne and Ne well, 1983). Dynamic energy budget (DEB) models, by contrast, describe the rates at which organisms assimilate and utilise energy for maintenance, growth and reproduction. The DEB theory is based on physical and chemical assumptions for individual energetics (Kooijman, 2010), whereas SFG models are based on energetics ca Iculated empirically from allometric relationships (Nisbet et al., 2000; Van der Meer, 2006). DEB modelling has also been applied to various bivalves ( e.g. Van Haren and Kooijman, 1993; Ren and Ross, 2005; Ca rdoso et al., 2006; Rosland et al. 2009).

The first DEB model for $C$. gigas was developed by Pouvreau et al. (2006). It was subsequently improved by Bourlès et al. (2009). This model simulates changes in flesh dry mass (growth and repr oduction) in adult C. gigas, from two environmental parameters: temperature and food concentratio $\mathrm{n}$. In the initial model, Pouvreau et al. (2006) used chlorophyll a (chl a) concentration as proxy for food availability and fo $r$ the forcin $g$ of the model, but recommend ed the imp rovement of this proxy in subseq uent studies. In the second version of the m odel, Bourlès et al. (2009) showed that the replacement of chl a by phytoplankton concentration refined the description of $t$ he food available to the oyster throughout the year. This first individual bio-energetic model for adult $C$. gigas has also been used at various scales, including those of the population (Bacher and Gangnery, 2006) and ecosystem (Grangeré et al., 2009, 2010), and has been adapted for the larval stage of $C$. gigas (Rico Villa et al., 2010). This model seems to be the first suitable for use in different environments and at $d$ ifferent biological scales without re quiring a significant change in structure or parameterisation. Ren and Schiel (2008), in New Zealand, also developed a bioenergetic model for $C$. gigas based on the DEB theory, with parameters very d ifferent in some cases from the values of van der Veer et al. (2006). Application of the model of Ren and Schiel (2008) to other sites a nd environmental conditions has, however, yet to be demonstrated. Indeed, this model has been validated solely for a duration of five months in winter, excluding the period of gamete release, and in particular for sets of environmental conditions in which chl a concentrations are low (between 0.2 and $3 \mu \mathrm{g} \mathrm{L}^{-1}$ ) and temperatures are restricted to the 12 to $16^{\circ} \mathrm{C}$ range.

In this context, the aim of this study was to assess the robustness and "generic" nature of the oyster DEB model by applying it to the principal oyster-growing regions of the Channel and 
Atlantic coasts. We tested the model on a diverse range of oyster-farming sites, with contrasting environmental and pro duction conditions, representative of the dive rsity of French production. The sites studied were the basins of Arcachon and Marennes-Oléron, the bay of Quiberon, Mont-Saint-Michel Bay, Baie-des-Veys and Brest $\mathrm{H}$ arbour. For each of these regions, the data series cho sen for each single sit e comprised measurements over time of the forcing variables (te mperature and phytoplankton con centration) and the validation data (dry flesh mass of the oysters).

\section{Materials and methods}

\subsection{Study sites}

Six sites along the French Channel and Atlantic coast $s$ (Fig. 1) were selected $f$ or study, based on their contrasting environments in terms of both thermal an $d$ trophic conditions. Following a south-to-north gradient and, as a fu nction of the years studied, the study sites were: 1) Tès (1993-1994) in the Arcachon Basin (AR; Fig. 1, inset 1); 2) D'Agnas (2007) in the Marennes-Oléron Basin (MO; Fig. 1, inset 2); 3) Men er Roué (1999 to 2001) in Quiberon Bay (QB; Fig. 1, inset 3); 4) Lanvéoc (2008) in Brest Harbour (BR, Fig. 1, inset 4); 5) SaintBenoît (2003) in Mont-Saint-Michel Bay, for three age classes (1, 2 and 3 years) of $C$. gigas (CA, Fig. 1, inset 5); 6) Grandcamp (March 2002 to September 2003) in Baie-des-Veys (BV, Fig. 1, inset 6).

\subsection{Forcing and validation variables}

The environmental factors governing the gro wth and reproduction of oysters are the temperature of the seawater and $t$ he concentration of phytoplankton ( after identification of the microalgal species present). Data for th ese factors are supplied by the Coastal Environment and Aquacultural Resources Laboratories of IFREMER (http://wwz.ifremer.fr/institut_eng/Marine-science/Monitoring). Temperature is measured continually (high-frequency recording) by multiparameter probes (Hydrolab DS5-X OTT probe, NKE YSI probe ). Phytoplankton was identified a nd counted in $1 \mathrm{~L}$ sa mples of seawater taken from ea ch site at a depth of 1 meter below the surface on a fortnightly or monthly basis depending on the site. The $p$ hytoplankton samples were fixed in Lugol's solution by a standardised protocol (Aminot and Kérouel, 2004), in t he framework of the IFREMER national REPHY network for phytoplankton monitoring. Some non-edible algae impede the growth of C. gigas during massive blooms (Bourlès et al., 2009). This was confirmed in our study, for Leptocylindrus minimus at Marennes-Oléron in summer 2007 and Lepidodinium chlorophorum at Quiberon Bay in September 2001. The model was first tested on total counted phytoplankton spe cies, and the poor match observed between simulated and measured oyster growth for the se two specific cases led us to exclude these non-edible species for the forcing of the model. L. minimus and L. chlorophorum did $\mathrm{n}$ ot bloom massively at any other occasion o $r$ any site. Except at MO in summer 2007 and QB in September 2001, the annual mean concentration of these two species was less than $5 \%$ of the total number of cells per $L$.

The mean individual dry flesh mass (DFM) of $C$. gigas, which was measured at the six sites, at regular intervals with about 10 samples taken annually, was used to validate the model. This variable was obtained by dissecting 30 oysters, freeze-drying the flesh for 48 to 72 hours (depending on the size), then weighing the dried tissue (to the nearest $\mathrm{mg}$ ). In total, 11 sets of data relating to changes in the dry flesh mass of $C$. gigas were used as the validation data for the model, for the various years studied at the six sites. 


\subsection{The oyster-DEB model}

The DEB model of oyster growth and reproduction used in this study is that descr ibed in detail by Bourlès et al. (2009). Note that 1) the DEB theo ry (Kooijman 2010) is based on biological hypotheses describing the flux of energy within an organism in terms of differential equations and parameters specific to each species, estimated independently of environmental conditions; 2 ) one fe ature unique to DEB models is the use of a single set of processes and parameters for $C$. gigas, over a large range of forcing variables; 3 ) the parameter $X_{K}$, a component of the law gove rning ingestion, is the only freely calibrated parameter of the oyst er-DEB model required to obtain the best possible fit between simulated and observed growth data for oy sters. The oyster-DEB model was implemented with STELLA ${ }^{8} 8.0$ software.

The initial conditions of the state variables of the model (dry mass of the soma or structure $V$, energy reserves $E$ and the reserves devoted to reprodu ction $E_{R}$, expressed in terms of energy, in J) were adju sted for each set of data tested (Table 1). The structural volume $V$ was calculated according to the oyster length $(L)$, using the shape coefficie nt $\delta$ and the formulae $V=(\delta . L)^{3}$. The initial valu e of $E$ and $E_{R}$ were deduced to obtain the correct initial total dry mass, as well as realistic initial values for the ene rgy density and gonado -somatic index $\mathrm{Gl}$ defined as the ratio betwe en the gonad mass and the total flesh mass. Reported temperature and food abundance for the days preceding the start of each monitoring campaign were used to evaluate the distributio $n$ of the en ergy in the animals between the structure, the reserves and the reproductive compartment.

For each simulation, the quality of model adjustment was estimated by fitting a linear regression between observed and simulated values, and comparing th e resulting slope and intercept of significant regressions to 1 and 0 , respectively.

\section{Results}

\subsection{Forcing variables: environmental conditions}

The annual temperature profiles o btained at the various sites high light the north-south temperature gradient a pplying to the oyster-rearing site $s$ and are characteristic of the temperature regions of the Channel/Atlantic co asts of France (Figs. $2 \& 3$ ). The minimum temperatures in winter (about $6-8^{\circ} \mathrm{C}$ ) are largely similar for the six sites along the north-south gradient. A weak east-west gradient was also observed along the Channel coast, with minimal temperatures of $6^{\circ} \mathrm{C}$ measured at $\mathrm{B}$ aie-des-Veys (BV) in t he east. By contrast, summer temperatures followed a clear latitud inal gradient, with a maximum value of $24^{\circ} \mathrm{C}$ recorded for Arcachon (AR) in 1994, and lower values of $20^{\circ} \mathrm{C}$ recorded in the more northerly ecosystems, i.e. Brest Harbour (BR), Mont-Sa int-Michel Bay (CA) an d Baie-des-Veys (Fig. 3).

Phytoplankton concentrations differed between sites, and between years at a given site (Figs. 2 \& 3). The lowest mean ann ual concentration of phytoplankton was $1.1 \cdot 10^{5} \mathrm{cell} \mathrm{L}^{-1}$, at QB in 1999 and AR in 1993, whereas the highest mean ann ual concentration of phytoplankton was $5.7 \cdot 10^{5}$ cell $\mathrm{L}^{-1}$ for $\mathrm{MO}$ in 2007 . Th e second h ighest mean annual concentration of phytoplankton was $2.9 \cdot 10^{5}$ cell $L^{-1}$ for $B R$ in 2008 . For the oth er sites, depending on the year considered, a nnual mean values were between 1 and $2 \cdot 10^{5} \mathrm{cell} \mathrm{L}^{-1}$. Phytoplankton blooms were observed mostly in spring (March/April) at all the sites studied (except BR), and there were also some blooms in the summer (June to August) and autumn (end of September for QB and BR; start of No vember for AR). The most extensive blooms were observed at $\mathrm{MO}$, where concen trations reached about $35 \cdot 10^{5} \mathrm{cell} \mathrm{L}^{-1}$ in April 2007. At 
the other sites, the phytoplankton blooms were less extensive, wit $h$ concentrations of between 2.7 and $17.4 \cdot 10^{5}$ cell L $^{-1}$ (Figs. $2 \& 3$ ).

\subsection{Validation data: oyster growth}

The dry flesh masses of the oysters (DFM) differed markedly between sites and as a function of the period considere $\mathrm{d}$, with rang es of $0.50 \mathrm{to} 2.32 \mathrm{~g}$ at the end of the monitoring period and 0.22 to $3.34 \mathrm{~g}$ bef ore spawning (Figs. 4, 5 and 6, sy mbols). Differences between age classes were also observed for the CA site (Fig. 6). The $\mathrm{i}$ nitial masses were between 0.03 and $0.07 \mathrm{~g}$ for the 1-y old oysters, and between 0.26 an $\mathrm{d} 1.11 \mathrm{~g}$ for the 2-y and 3-y old oysters. The final masses, measured at the end of the monitoring period, were between 0.46 and $1.16 \mathrm{~g}$ for $1-\mathrm{y}$ old oysters, 1.11 and $1.95 \mathrm{~g}$ for $2-\mathrm{y}$ old oysters and up to $2.32 \mathrm{~g}$ for $3-\mathrm{y}$ old oysters.

At the various sites, two distinct periods in the year were ide ntified in the profile of change in DFM of oysters of 2-yr and 3-yr old over time: i) a period of sustained spring growth until spawning in summer and ii) a period of slower growth in the autumn, with no growth or even shrinkage in winter (Figs. 4, 5 an d 6). One-year old oysters (QB99, QB01 and CA03/1) exhibited a positive growth over the fall and wint er (Figs. 5,6). Mean daily growth rates for the 11 sets of data were $3.92 \%$ in spring (approximately corresponding to the March-June period), versus $0.17 \%$ in the autumn (end of August to November), corresponding to a spring growth rate about 20 times higher than that in the autumn. In autumn and winter, $t$ here was frequently no growth at all (AR94, QB99, BV, CA, for all thr ee age classes) or even a loss of mass (MO07, QB00, BR08), except for QB01, where estimated growth rate was positive (0.82) in the autumn.

In terms of spawning, the mass loss corresponding to gamete release for adult oysters of two and three years of age was larger in situations of strong spring growth (Figs. 4, 5 and 6). Thus, at Arcachon, the mass loss observed during gamete release was $27 \%$ and $54 \%$ of the mean mass of $C$. gigas before spawning in 1993 and 1994, respectively, for estimated daily growth rates in spring of $1.3 \%$ in 1993 and $2.4 \%$ in 1994 (Fig. 4). For 1-y oysters, monitoring at the CA a nd QB sites did not d etect laying, although oysters of this age are ca pable of laying eggs and small losses of mass were observed (Figs. 5 and 6-CA).

\subsection{Simulated growth of C. gigas}

For the 11 sets of data, the simulated values for oyster dry flesh mass (DFM) obtained with the model matched the observed values, for both the periods of a ctive growth, mostly in the spring, and periods of mass loss or stalled growth in autumn and winter (Figs. 4, 5 \& 6, Table 2). For seven of the 11 sets of data, the values of $R^{2} f$ or regressions of obser ved DFM against simulated DFM exceeded $0.91 \quad(p<0.0001)$; the slopes were between 0.841 and 1.105 and the intercepts of these regression lines were between -0.155 and 0.198 (Table 4). For the remaining four data sets (AR93, QB99, MO07, CA03/2), $\mathrm{R}^{2}$ was between 0.8 and 0.9 $(p<0.001)$. For AR93 and QB99, these slightly lower values reflect a slight underestimation of spring growth (Figs. 4 \& 5). For $\mathrm{MO07}$, they correspond to an overestimation of growth that was observed from May to mid July 2007 (Fig. 4), and for CA03 /2, they reflect an underestimation of the winter growth of 2-y old oysters (Fig. 6).

The amplitude and period of gamet e release, as simulated by the model, were consistent with observed values for the seven monitoring campaigns for 2-y and 3-y old oysters (Figs. 4 and 6). Simulations for 1-y old oysters showed either low levels of ga mete release (QB99, QB01, Fig. 5), or no gamete release (QB00 and CA03/1, Figs. 5, 6). For QB00, the decrease in DFM observed in 1-y old oysters during the summer was correctly simulated by the model, 
which predicted a large loss of mass in the summer following a period of sustained growth in the spring (Fig. 5).

The values of the half-saturation co efficient $X_{K}$ were between 260 and $700 \cdot 10^{3}$ cell L $^{-1}$ for the 11 data sets used, whereas mean annual phytoplankton concentra tions were estimated at 110 to $570 \cdot 10^{3}$ cell L-1 (see section 3.1). Most of the $X_{K}$ values for the various sites were close to $300 \cdot 10^{3}$ cell $\mathrm{L}^{-1}$, but two sites had exceptionally high $X_{K}$ values: greater than 450 . $10^{3}$ cell L $^{-1}$ at Baie-des-Veys (Fig. 6) and $700 \cdot 10^{3}$ cell L $^{-1}$ at Marennes-Oléron (Fig. 4). There was a significant linear relationship between $X_{K}$ and the mean annual con centration of phytoplankton for all 11 data sets (Fig. 7). This relationship can be expressed as follows: $X_{K}$ $=1.05$. [phyto] $+163.48\left(R^{2}=0.77 ; n=11\right)$. Thus, $t$ he highest estimates of $X_{K}$ were associated with the highest mean annual phytoplankton concentrations.

\section{Discussion}

\subsection{Generalisation of the oyster-DEB model}

The growth dynamics of $C$. gigas were correctly reproduced by the oyster-DEB model $i$ ) at all sites tested; ii) for the three age classes studied and iii) throughout the year, both during periods of active growth (essentially in the spring, but sometimes in the summer and autumn) and during periods of mass loss in autumn/wi nter and more abrupt periods of mass loss in the spring and summe $r$ due to sp awning (Figs. 4 to 6; $T$ able 2). The oyster-DEB mode I successfully reproduced the contrasting growth profiles of spring and the autu mn-winter period for three age classes of oyste rs reared simultaneously in the same environme nt (CA, Mont-Saint-Michel Bay). All the key periods in the growth cycle of farmed C. gigas, from the end of the spat stage ( i.e. one year onwards) were thus fait hfully simulated, complementing the validation already re ported for larval growth (Rico-Villa et al. 2009). This validation thus suggests that the mod el may be considered generic, not only at th e geographic scale (several oyster-rearing sites tested), but also over time (application of the model at the same site over the course of several years ) and for oysters of different age classes. This is the first validation of a bioenerg etic model for $C$. gigas based on a single set of parameters, in several contrasting e nvironmental conditions, with only one parameter $X_{K}$ requiring adjustment for each data set. A similar appr oach is curre ntly being developed for another species of ecological and aquacultural importance, the blue mussel Mytilus edulis (AlunnoBruscia et al. in preparation).

The mass losses asso ciated with the release of gametes in the summer were s uccessfully simulated by the model, with a certain consistency, regardless of the age of the o ysters ( 1 to 3 years) and the environmental conditions (Figs. 4, 5 and 6). The simulated dates of gamete release were also clo se to the actu al spawning dates observed in situ. No gamete release was observed for 1-y old oysters in Mont-Sai nt-Michel Bay in 2003. By contras t, gamete release accounted for more than $50 \%$ of dry flesh mass loss for the oysters in Brest Harbour in 2008 and in the Arcachon Basin in 1994. Such contrasts are not unusual in C. gigas (Berthomé et al., 1986). These variations in gamete release highlight differences in the flow of energy and matter between the two principa I compartments of the individual, $t$ he soma and the reproductive co mpartment, through the applicatio $n$ of the same energy allocation rules to all life stages of the oyster. In younger oysters (smaller in size), a higher proportion of energy is devoted to growth of the soma than to gamete production, whereas the reverse is true for older oysters. These observations are consistent with the hypothesis un derlying DEB theory (Kooijman, 2010), according to which the costs of maintaining the soma increase with its size, thereby asymptotically limiting growth in the largest oysters, whereas the investment in reproduction continues to increase proportionally with the size of the soma. One recent study attempted to improve the description of reproductive effort in C. gigas 
through the use of a DEB model. This st udy was carried out at three of the six sites studied here (Arcachon, Marennes-Oléron and Brest Harbour) in the years 2008 and 2009; it has le d to the prop osal of a $\mathrm{n}$ ew set of DEB parameters and a formalism different from that of Bourlès et al. (2009), with the addition of a state variable describing gamete production in the spring (Bernard et al., in press -this issue). A comparison between the simulations obtaine $d$ with the two versions of the model (those of Bourlès et al. (2009) and Bernard et al. (in press -this issue)) indicated that the model of Bernard et al. better describe d and quantified the reproductive effort.

The demonstration in t his work of the genera lised application of an oyster-DEB model at different sites nonetheless raises questions about the correctness of the $v$ alues of parameters estimated in various studies (van der Veer et al., 2006; Pouvreau et al., 2006; Bourlès et al., 2009). Another bio-energetic model based on DEB theory has been developed for $C$. gigas by Ren and Schiel (2008). These authors spe cified that their model had been applied to and validated in condition s of Pacific oyster rearing specific to New Zealand. The values of the parameters of the Ren and Schiel model (2008) are different fr om those estimated here: $k=0.65$ vs 0.45; $\left[E_{G}\right]=2900$ vs $1900 \mathrm{~J} \cdot \mathrm{cm}^{-3} ;\left[E_{M}\right]=5900$ vs $2295 \mathrm{~J} \mathrm{~cm}^{-3}$; $\left[p_{M}\right]=18.5$ vs $24 \mathrm{~J} \mathrm{~cm}^{-3} \mathrm{~d}^{-1}$, for the estimations of Ren and Schiel (2008) and Bourlès et al. (2009), respectively. Ren \& Schiel (2008) based their parameters estimation on data collected during a short period (6 months from May to October) under a narro $\mathrm{w}$ range of temperatures $\left(13-15^{\circ} \mathrm{C}\right)$; moreover no spawning for $C$. gigas occurred, which impedes any validation of the $k$ value used by these authors. This may partly explain the differences in the DEB parameters between the two s tudies. The validations of these two models, which were developed independently for the same species, highligh $t$ the need to work towards homogeneity in parameter values, $f$ or the construction of a unique, standard growth model based on DEB theory (Kooijman, 2010). The recent work of Bernard et al. (in press -this issue) represents an additional step towards the harmonisation of DEB paramete rs for $C$. gigas.

\subsection{Phytoplankton concentration as a proxy for food availability in the oyster-DEB model}

In a simplif ied modelling approach, we decide $d$ to use phytoplankton concentration as a proxy for $f$ ood ingestion by oyst ers. We co nfirmed the relevance of this proxy for the simulation of $C$. gigas growth at several sites in Fran ce. In most b io-energetic models developed to simulate the growth of $C$. gigas, chlorophyll a concentration is used as the food proxy (e.g. Raillard et al., 1993, Barillé et al., 1997, Ren \& Schiel 2008). This was the case, in particular, in the first version of the oyster-DEB model (Pouvreau et al. 2006). However, Bourlès et al. (2009) showed that phytoplankton concentration was a more perti nent food proxy than chl $a$ in the rules governing ingestion in the DEB model, constituting in principle a good trophic indicator capable of reproducing the growth variations observed during the year. Bernard et al. (in press -this issu e) also showed that $p$ hytoplankton concentration was sufficient to simulate the reproductive effort of C. gigas at various French sites, with the exception of Bourgneuf Bay, a site for which th $e$ available data for phytoplankton did no $t$ coincide precisely with the site at which oyster growth was monitored (Barillé et al., in press this issue). The phytoplankton concentration may not be available systematically in monitoring surveys. It is also more costly or time-consuming compared to chl $a$ and is not easily simulated by modelling. Despite these drawbacks, it is still in ou r view a more reliable and precise food proxy of bivalve diets than the chl a concentration which does not allow to distinguish the contribution of the main algae classes or groups. An alternative that could help to re ach a compromise between chl a and phytoplankton concentrations would be to use new in struments for continuous chlorophyll and phot osynthetic activity determination among different algae classes by excitation of pigments with coloured LEDs. 
This food p roxy can be used to distinguish between the respectiv e contributions of the principal species of microalgae identified as food sources for $C$. gigas and to identify blooms of non-edible algae tha $t$ are, in principle, not ingested (or assimilated in only very small quantities) by oysters. These blooms may devel op to densities exceeding $1 \cdot 10^{6} \mathrm{cell} \mathrm{L}^{-1}$, at times at which the oysters display no significant growth (Bourlès et al. 2009). In this study, $L$. minimus reached levels of more than $2 \cdot 10^{6}$ cell L $^{-1}$ in August 2007 at Marennes-Oléron, but there was no concomitant increase in DFM. In this particular case, the DEB model correctly simulated the mass of oyster flesh when the number of $L$. minimus cells was excluded from the forcing of the model. At Quib eron bay, L. chlorophorum was the speci es displaying massive proliferation $w$ ithout the slightest po sitive effect on oyster growth (Fleury et al., 2001); this species was withdrawn f or the month of September 2001 from the forcing of the model and the result was a good match between the observed and simulated growth of the oyster. Tetraselmis $s p$. and Kryptoperidinium foliaceum were previously subtracted from the concentration of total phytoplankton for forcing of the oyster-DEB model and simulation of the growth of $C$. gigas in an oyster pond (Bourlès et al. 2009). This neg ative effect of some particular algae when at high concentrations may provide an alternative explanation for the intriguing decrease in Crassostrea virginica food uptake measured in situ (with a pelagic ecosystem tunnel) by Comeau et al. (2010) during an autumnal bloom.

The alternative to this empirical approach, based on the subtraction of certain non-edible algae from the food sources of oysters, is to modify specifically the assimilation ef ficiency $(A E)$, fixed globally in the current set of parameters at a constant value of $75 \%$, regardless of the phytoplankton species present and their concentrations (Bourlès et al. 2009). This would make it possible to retain non-edible algae among the food potentially ingested by the oyster, but absorbed poorly, if at all (i.e. with $A E$ values that are either very low or ze ro). The assimilation efficiency of bivalves may vary according to th e species of algae ingested (e.g. Ren et al., 2006; for reviews in Bayne \& Newell 1983; Gosling 2003), with very low values of $A E$ reported in the case of Tetraselmis suecica for Crassostrea virginica (Romberger \& Epifanio 1981) and C. gigas (Boglino 2008) in particular, or the value of $A E$ may decrease as phytoplankton concentration increases (Kuenster 1988). Moreover, assimilation efficiency may be influenced by water temp erature, the organic fra ction of the food and non-edible inorganic matter (e.g. Hawkins et al. 1998; for a review see Gosling 2003) and probably displays seasonal variation due to te mporal changes in phyto plankton assemblages. Finally, there is a functional rela tionship between and interdependency of assimilation efficiency on gut capacity, the residence time of the food in the gut and ingestion rat e (Bayne \& Newell 1983). This relationshi $p$ cannot be explicitly formalised in the Holling-type II hyperbolic function describing the energy intake of an organ ism in DEB theory. It is also not possible to formalise differences in the feeding behaviour of $\quad C$. gigas with $r$ espect to different phytoplankton species.

\subsection{The environment-specific half-saturation coefficient $X K$}

The half-saturation coefficient $X_{K}$ for ingestion is the only parameter of this mod el freely adjusted for each environmental scenario, with values of $260 \cdot 10^{3}$ cell $\mathrm{L}^{-1}$ in Quiberon Bay (1999, Fig. 5) to $700 \cdot 10^{3}$ cell L ${ }^{-1}$ at Marennes-Oléron (2007, Fig. 7). The hig her value reflects poor trophic quality or low appetence of the oysters for the food available. $X_{K}$ is the only empirical parameter of the oyster-DEB model and it in tegrates all sources of variation linked to the trophic e nvironment, including the diversity of food sources and seasonal variations in the nutrit ive quality of food, flu ctuations of the selection of particle s before ingestion and variability in assimilati on efficiency as a function of the food actually ingested. In addition to this integration of environmental variability, $X_{K}$ also seems to be influenced by the age and/or size of oysters, as shown by the different $X_{K}$ values obtained for the three age classes of oysters in the same environment (Mont-Saint-Michel Bay, Fig. 6). This may be accounted for by variability in filtration, selection and/or ingestion capacities, due to 
differences in the range of prey size as a function of the size of $C$. gigas. Indeed, differences in food source between individuals of the same species but of different age classe $s$ have been demonstrated for other bivalves, such as the cockle Cerastoderma edule (Sauriau and Kang, 2000).

The adjusted values of the half-sa turation coefficient $X_{K}$ increase lin early with measured phytoplankton concentration (Fig. 7), indicating that the quality of the trophic resource and/or the appetence of the oysters for this resource decrease when phytopl ankton concentrations are high (e.g. Comeau et al., 2010). There are two probable explanations for this significant relationship: i) sites with high phytoplankton concentrations (e.g. MO07 which is also a very turbid site compared to the other sites; BR08) are generally of lower (or poorer) trophic quality than sites with lower phyto plankton concentrations (e.g. AR93 and AR94, QB fro m 1999 to 2001, CA02), accounting for the lowe $r$ growth rates of oyster $s$ at sites $w$ ith high phytoplankton abundance compared to sit es with lo $w$ abundance, for th e same phytoplankton concentration; ii) the physiological flexibility of $C$. gigas, particularly in terms of filtration and food selection organs, gills and labial palps (Barillé et al., 2000; Dutertre et al., 2007), allows the bivalve to adapt to differen $t$ particle loads. A high particle load (turbid environment) may lead, in particular, to a decrease in gill area and, thus, to a decrease in the capacity of the animal to filter its food. In the oyster-DEB model, this leads to an increase in $X_{K}$, resulting in a positive linear relationship between this factor and the mea $\mathrm{n}$ annual concentration of phytoplankton.

\section{A multivariate approach to the feeding response in DEB}

Other pathways should be explored to com pensate for the e mpirical estimation of $X_{K}$, which varies between site $s$, making it p ossible to d evelop a "multivariate" approach to energy acquisition in $C$. gigas that is not based on a single food proxy and/or a functional response simplified with respect to the alime ntary physiology of $C$. gigas. One of these a Iternative pathways is based on the inclusion of several food sources into the ingestion law, with the aim of better reflecting the contribution of different compartments of the seston as food sources for filter-feeding bivalves, and thus the contribution of these compartments to growth (e.g. Cognie et al., 2003; Decottignies et al., 2007; Marin Leal et al., 2008; Lefebvre et al., 2009). In environments with high concentration s of inorganic matter, th e effect of inedible mineral particles on bivalve filtration ma y be explicitly integrated into the ingestion law (Kooijman, 2006). Ren (2009) tested this approach with the mussel Perna canaliculus. The contribution of suspended organic matter to the food available (expressed in terms of chl a concentration) was integrated into a formulation of the functional response $f$, to simulate the growth of cockles ( C. edule) and mussels ( M. edulis) in the Oosterschelde (Troost et al., 2010). This contribution was found to be significant in cockles at certain sites. Similarly, the contribution of different genera or families of phytoplankton, the relative contributions of the pelagic phytoplankton and microphytobenthos at certain sites (Marin Leal et al., 2008; Lefebvre et al., 2009), like that of protists including ciliated and flagellated organisms (Dupuy et al., 1999; Trottet et al., 2007), could be formalised in terms of $f$. The negative effect of certain algae on the ingestion and growth of filter feeders ( e.g. Chauvaud et al., 2001) and the effect of certain toxic agents (h eavy metals, toxic chemicals of natural or anthropogenic origin) or even diseases likely to aff ect the alimentary physiology of bivalves (Flye-SainteMarie et al., 2009) could also be integrated into the structure of the model, through effects on feeding processes or maintenance costs (Casas and Bacher, 2006; Flye-Sainte-Marie et al., 2009).

Another possibility is to model th e various p rocesses involved in the feeding of $C$. gigas (filtration, ingestion, assimilation) in the same way as has been done for the mussel $M$. edulis (Saraiva et al., 2011), making use of the concept of "synthesising un its" (Kooijman, 1998, 2010). Synthesising units (SU) are generalized enzymes that bind (with a fixed probability) to 
substrate molecules (ar riving according to a Poisson process), to synthesise products, thereby transforming the arrival fluxes of substrates into a production flux of products (Lika and Papadakis, 2009). If SU are id entified with an individual filter feeder, and the product with reserves, the transformation rate is given di rectly by the functional response $f$ (Saraiva et al., 2011). This new modelling approach, i nvolving application of the SU concept, has provided a satisfactory mechanistic de scription of the feeding processes of $M$. edulis based on published data and has dealt with variability in the amount and quality of food, although uncertainties relating to ingestion in the presen ce of pseudofaeces production remain. The large set of studies pu blished on the feeding physiology of C. gigas, and possible ne w dedicated experiments, may prove useful for the implementation of a similar app roach for Pacific oyster.

\section{Acknowledgements}

Y. Bourlès was supported by funding from Ré gion Poitou-Charentes and IFREMER during his PhD project. We wo uld like to thank the IFREMER staff at all the coastal laborat ories for technical assistance during field surveys in the various sit es, including in particular those involved in the REPHY and REMORA monitoring networks run by IFREMER. We also than $\mathrm{k}$ the members of the Eu ropean Research Grou p AquaDEB (http://www.ifremer.fr/aquadeb/) for stimulating discussions and useful comments.

\section{References}

Alunno-Bruscia1,M., Rosland, R., Strand, Ø., Naustvoll, L., Bacher, C., Cranford, P., Grant, J., Smaal, A.C. Multi-site comparison of the gr owth variability for cultu red blue mussels using Dynamic Energy Budgets (DEB). In preparation for Aquaculture.

Aminot, A., Kérouel, R., 2004. Hydrologie des écosystèmes marins : paramètres et analyses. In: Méthodes d'analyse en milieu marin. Ed. Ifremer Quae, 336 pp.

Bacher, C., Duarte, P., Ferreira, J.G, Héral, M., Raillard, O., 1998. Assessm ent and comparison of the Ma rennes-Oléron Bay (France) and Carlingford Lough (Ireland) carrying capacity with ecosystem models. Aquat. Ecol. 31, 379-394.

Bacher, C., Gangnery, A., 2006. Use of dynamic energy budget and individual based models to simulate the dynamics of cultivated oyster populations. J. Sea Res. 56, 140-155.

Barillé, L., Lerouxel, A., Dutertre, M., Haure, J., Barillé, A.-L., Pouvreau, S., Alunno-Bruscia, M. In press. Growth of the Pacific oyster (Crassostrea gigas) in a high-turbidity environment: comparison of model simulations by using Scope for Growth vs Dynamic Energy Budgets. J. Sea Res. -this issue.

Barillé, L., Héral, M., Barill é-Boyer, A.L., 1997. Modélisation de l'écophysiologie de l'huître Crassostrea gigas dans un environnement estuarien. Aquat. Living Resour. 10, 31-48.

Barillé, L., Haure, J., Cognie, B., Leroy, A., 20 00. Variations in pallial organs and eulaterofrontal cirri in response to high particulate matter concentrations in the oyster Crassostrea gigas. Can. J. Fish. Aquat. Sci. 57, 837-843.

Bayne, B.L., Newell, R.C., 1983. Physiological energetics of marine mollucs. In: Saleuddin A.S.M., Wilbur K.M. (Eds.), The Mollusca, vol. 4. Academic Press, London, pp. 407-515

Berthomé, J.P., Prou, J., Bodoy, A., 1986. Pe rformances de croissance de l'huître creuse Crassostrea gigas (Thunberg) dans le bassin d'élevage de Marennes-Oléron entre 1979 et 1982. Haliotis 15, 183-192. 
Bernard, I., De Kermoysan, G., Pouvreau, S. In Press. Effect of phytoplankton and temperature on the rep roduction of the pacific oyster Crassostrea gigas: investigation through DEB theory. J. Sea Res. This issue.

Boglino, A., 2008. Les espèces phytoplanctoniques majeures des côtes a tlantiques françaises sont-elles équivalentes pour l'ingestion et la $\mathrm{cr}$ oissance de l'huître cre use Crassostrea gigas ? Réponse par le biais d 'une approche expérimentale. Rapport de Master 2 Sciences de I'Univers Environnement Ecologie, Université Pierre et Marie Curie - Paris 6, 46 pp.

Bourlès, Y., Alunno-Bruscia, M., Pouvreau, S., Tollu, G., Leguay, $\quad$ D., Christophe, A., Goulletquer, P., Kooijman, S.A.L.M., 2009. Modelling grow th and reproduction of the Pacific oyster Crassostrea gigas: Advances in the DEB-oyster model through application to a coastal pond. J. Sea Res. 62, 62-71.

Buestel, D. Ropert, M., Prou, J., Goulletquer, P. 2009. History, status and future of oyester culture in France. J. Shellfish Res. 28, 813-820.

Campbell, D.E., Newell, C.R., 1998. MUSMOD, a production model for bottom culture of the blue mussel Mytilus edulis (L.). J. Exp. Mar. Biol. Ecol. 219, 171-203.

Cardoso, J.F.M.F., Witte, J.I.J., Van der Veer, H.W., 2006. Intra-and interspecies comparison of energy flow in some North Atlantic bivalve species by means of the Dyna mic Energy Budget (DEB) theory J. Sea Res. 56, 182-197.

Casas, S., Bacher, C., 2006. Mod elling trace metal ( $\mathrm{Hg}$ and $\mathrm{Pb})$ bio accumulation in the Mediterranean mussel, Mytilus galloprovincialis, applied to environmental monitoring. J. Sea Res. 56, 168-181.

Chauvaud, L., Donval, A., Thouzea u, G., Paulet, Y.M., Nezan, E., 2001. Variation s in food intake of Pecten maximus (L.) from the Bay of Brest (France): Influence of environmental factors and phytoplankton species composition. Life Sci. 324, 1-13.

Cognie, B., Barillé, L., Massé, G., Beninger, P.G., 2003. Selection and processing of large suspended algae in the oyster Crassostrea gigas. Mar. Ecol. Prog. Ser. 250, 145-152.

Comeau, L., Sonier, R., Lanteigne, L., Landry, T. 2010. A novel approach to measurin $g$ chlorophyll uptake by cultivated oysters. Aquacult. Eng. 43, 71-77.

Decottignies, P., Beninger, P.G., Ri ncé, Y., Robins, R.J., Riera, P., 2007. Exploitation of natural food sources by two sympatric, invasive suspension-feeders: Crassostrea gigas and Crepidula fornicata. Mar. Ecol. Prog. Ser. 334, 179-192.

Dowd, M., 1997. On predicting the growth of cultured bivalves. Ecol. Model. 104, 113-131.

Duarte, P., Fernández-Reiriz, M.J. , Filgueira, R., Labarta, U., 2010 . Modelling mussel growth in ecosystems with low suspended matter loads. J. Sea Res. 64, 273-286

Dupuy, C., Le Gall, S., Hartmann, H.J., Bréret, M., 1999. Retention of ciliates and f lagellates by the oyster Crassostrea gigas in French Atlantic coastal ponds: Protists as a trophic link between bacterioplankton and benthic su spension-feeders. Mar. Ecol. Prog. Ser. $177,165-175$.

Dutertre, M., Barillé, L., Haure, J., Cognie, B., 2007. Funct ional responses associated with pallial organ variations in the Pacific oyster Crassostrea gigas (Thunberg, 1793). J. Exp. Mar. Biol. Ecol. 352, 139-151.

Fleury, P.G., Goyard, E., Mazurié, J., Claude, S., Bouget, J.F., Langlad e, A., Le Co guic, Y., 2001. The assessing of the Pacific oyster (Crassostrea gigas) rearing performances by the Ifremer/REMORA network: method and first results (19 93-98) in Brittany (France). Hydrobiologia 465, 195-208. 
Flye-Sainte-Marie, J., Jean, F., Paillard, C., Kooijman, S.A.L.M., 2009. A quantitative estimation of the energetic cost of br own ring disease in the Manila clam using Dyna mic Energy Budget theory. J. Sea Res. 62, 114-123.

Grangeré, K., Ménesguen, A., Lefebvre, S., Ba cher, C., Pouvreau, S., 2009. Modelling th e influence of environmental factors on the ph ysiological status of the Pacific oyster Crassostrea gigas in an estuarine embayment: The Baie des Veys (France). J. Sea Res. 62, 147-158.

Grangeré, K., Lefebvre, S., Bacher, C., Cugi er, P., Mén esguen, A., 2010. Mod elling the spatial heterogeneity of ecologica I processes in an intertidal estuarin e bay: dyn amic interactions between bivalves and phytoplankton. Mar. Ecol. Prog. Ser. 415, 141-158.

Grant, J., Archambault, M., Bacher, C., Cranford, P., 2003. Integration of modelling and GIS in studies of carrying capacity for bivalve aquaculture. J. Shellfish Res. 22, 332.

Gosling, E. M. 2003. Bivalve molluscs. Biology, ecology and culture. Blackwell Science.

Hawkins, A.J.S., Bayne, B.L., Boug rier, S., Hér al, M., Iglesias, J.I.P., Navarro, E., Smith, R.F.M., Urrutia, M.B., 1998. Some general $r$ elationships in comparing the feeding physiology of suspension-feeding bivalve molluscs. J. Exp. Mar. Biol. Ecol. 219, 87-103.

Héral, M., 1993. Why carrying capacity models are useful tools for management of bivalve molluscs culture. In: Dame, R.F. (Ed.), Bivalve Filter Feeders in Estuarine and Coastal Ecosystem Processes. Springer-Verlag, Berlin, pp. 455-477.

Kooijman, S.A.L.M., 2010 . Dynamic energy and mass budgets in biological systems. $3^{\text {rd }}$ edition, Cambridge Univ. Press, Cambridge, 514 pp.

Kooijman, S.A.L.M., 2006. Pseudo-faeces production in bivalves. J. Sea Res. 56, 103-106.

Kooijman, S., 1998. The synthesizing unit as a model for the stoichiometric fusion

and branching of metabolic fluxes. Biol. Chem. 73, 179-188.

Kuenster, S.H. 1988. T he effects of the brown tide alga on the feeding physiology of Argopecten irradians and Mytilus edulis. M.Sc. thesis, State University of New Yo rk at Stony Brook.

Lefebvre, S., Marin Leal, J.C., Dub ois, S., Orvain, F., Blin, J.L., Bataillé, M.P., Ourry, A., Galois, R., 2009. Seasonal dynamics of trophic relationships among co-occurin $g$ suspension-feeders in two shellfish culture dominated ecosystems. Estuar. Coast. Shelf. Sci. 82, 415-425.

Lika, K., P apadakis I.A., 2009. Modelling $t$ he biodegradation of $p$ henolic compounds by microalgae. J. Sea Res. 62, 135-146.

Marin Leal, J.C., Dubois, S., Orvain, F., Galois, R., Blin, J.L., Ropert, M., Bataillé, M.P., Ourry, A., L efebvre, S., 2008. Stab le isotopes $\left(\delta^{13} \mathrm{C}, \delta^{15} \mathrm{~N}\right)$ and modell ing as tools to estimate the trophic ecology of cultivated oysters in two co ntrasting environments. Mar. Biol. 153, 673-688.

Nisbet R.M., Muller, E.B., Lika, K., Kooijman, S.A.L.M., 2000. From molecules to ecosystems through dynamic energy budget models. J. Anim. Ecol. 69, 913-926.

Pouvreau, S., Bourlès, Y., Lefebvre, S., Gangnery, A., Alunno-Bruscia, M., 2006. Application of a dynamic energy budget model to the Pacific oyster, Crassostrea gigas, reared under various environmental conditions. J. Sea Res. 56, 156-167.

Raillard, O., Deslous-Paoli, J.M., Héral, M.,R azet, D., 1993. Modélisatio n du comportement nutritionnel et de la croissance de l'huître japonaise Crassostrea gigas. Oceanol. Acta 16, 73-82. 
Ren, J.S., Ross, A.H., 2001. A dynamic ener Crassostrea gigas. Ecol. Model. 142, 105-120.

gy budget model of the Pacific oyster

Ren, J.S. and Ross, A.H., 2005. Environmen tal influence on mussel growth: A dynamic energy budget model and its application to th e greenshell mussel Perna canaliculus. Ecol. Mod. 189, 347-362.

Ren, J.S., Ross, A.H., Hayden, B.J., 2006. Comparison of assimilation efficiency on diets of nine phytoplankton species of the greenshell mussel Perna canaliculus. J. Shellfish Res. 25, 887-892.

Ren, J.S., Schiel, D.R., 2008. A dynamic energy budget model: parameterisation and application to the Pacific oyster Crassostrea gigas in New Zealand waters. J. Exp. Mar. Biol. Ecol. 361, 42-48.

Ren, J.S., 2009. Effect of food quality on energy uptake. J. Sea Res. 62, 72-74.

Rico-Villa, B., Bernard, I., Robert, R., Pouvreau, S., 2010. A Dynamic Energy Budget (DEB) growth model for Pacific oyster larvae, Crassostrea gigas. Aquaculture 305, 84-94.

Romberger, H.P., Epifanio, C.E., 1981. Comparative effects of diets consisting of one or two algal species upon $t$ he assimilation efficiencies and growth of juvenile oysters, Crassostrea virginica (Gmelin). Aquaculture, 25, 89-94.

Rosland, R., Strand, Ø. , Alunno-Bruscia, M., Bacher, C., Strohmeier, T., 2009. $\quad$ Applying Dynamic Energy Budg et (DEB) theory to simulate growth and bio-e nergetics of blue mussels under low seston conditions. J. Sea Res. 62, 49-61.

Ross, A.H., Nisbet, R.M., 1990. Dynamic models of growth and reproduction of the mussel Mytilus edulis L. Funct. Ecol. 4, 777-787.

Scholten, H., Smaal, A.C., 1998. Responses of Mytilus edulis L. to vary concentrations: testing EMMY, an ecophysiological model. J. Exp. Mar. Biol. Ecol. 219, 217-239.

Saraiva, S., van der Meer, J., Koo ijman, S., Sousa, T., 2011. Modelling feeding processes in bivalves: A mechanistic approach. Ecol. Mod. 222, 514-523.

Sauriau, P.G., Kang, C., 2000. Sta ble isotope evidence of benthic microalgae-based growth and secondary production in the suspension feeder Cerastoderma edule (Mollusca, Bivalvia) in the Marennes-Oléron Bay. Hydrobiologia 440, 317-329.

Smaal, A.C., Widdows, J., 1994. The scope for growth of bivalves as an integrated response parameter in biological monitoring. In: Kramer K. (Ed.), Biomonitoring of Coastal Waters and Estuaries. CRC Press, Boca Raton, pp. 247-268.

Troost, K., 2010. Causes and effe cts of a hig hly successful marine invasion: Case-study of the introduced Pacific oyster Crassostrea gigas in continental NW European estuaries. J. Sea Res. 64, 145-165.

Troost, T. A., Wijsman, J. W. M., Saraiva, S ., Freitas, V., 2010. Modelling shel Ifish growth with dynamic energy budget models: an application for cockles and mussels in the Oosterschelde (southwest Netherlands). Phil. Trans. Biol. Sci. 365, 3567-3577.

Trottet, A., Roy, S., Tamigneaux, E., Lovejoy, C., 20 07. Importance of het erotrophic planktonic communities in a mussel culture e nvironment: the Grande Entree lagoon, Magdalen Islands (Québec, Canada). Mar. Biol. 151, 377-392.

van der Meer, J., 2006. Metabolic theories in ecology. Trends Ecol. Evol. 21, 136-140.

van der Veer, H.W., Cardoso, J.F. M.F., Van der Meer, J., 2006. The estimation of DEB parameters for various Northeast Atlantic bivalve species. J. Sea Res. 56, 107-124.

van Haren, R.J.F., Kooijman, S.A.L.M., 1993. Application of the dyn amic energy budget model to Mytilus edulis (L.). Neth. J. Sea. Res. 31, 119-133. 
Table 1. Initial model conditions estimated for each site (AR: Arcachon Basin, MO: Marennes-Oléron, QB: Quiberon Bay, BR: Brest Harbour, CA: Mont-Saint-Michel Bay, BV: Baie-des-Veys, for each year and each age class tested

\begin{tabular}{cccccc}
\hline Site & Year & $\begin{array}{c}\text { Age } \\
\text { class }\end{array}$ & Structure $\boldsymbol{V}(\mathbf{J})$ & Reserve $E(\mathbf{J})$ & $\begin{array}{c}\text { Reproductive } \\
\text { compartment } E_{R}(\mathbf{J})\end{array}$ \\
\hline \multirow{2}{*}{ AR } & 1993 & 2 years & 4000 & 800 & 2100 \\
& 1994 & 2 years & 3700 & 800 & 2000 \\
\hline \multirow{2}{*}{ MO } & 2007 & 3 years & 5800 & 1100 & 3000 \\
\hline \multirow{2}{*}{ QB } & 1999 & 1 year & 400 & 100 & 200 \\
& 2000 & 1 year & 250 & 50 & 150 \\
& 2001 & 1 year & 250 & 50 & 150 \\
\hline \multirow{2}{*}{ BR } & 2008 & 2 years & 5300 & 1200 & 2800 \\
\hline \multirow{2}{*}{ CA } & 2003 & 1 year & 600 & 100 & 300 \\
& 2003 & 2 years & 2200 & 500 & 3600 \\
\hline \multirow{2}{*}{ BV } & 2003 & 3 years & 6800 & 1400 & 2500 \\
\hline
\end{tabular}


Table 2. Linear regression of obser ved dry flesh mass aga inst simulated dry flesh mass; regression coefficient $R^{2}$, slope, intercept wit $h$ corresponding $p$ valu es of test ing slopes different from 1 and int ercept different from 0 . The 11 dat a sets tested were those for th $\mathrm{e}$ Arcachon basin in 1993 and 1994 (AR93, AR94), Marennes-Oléron in 2007 (MO07), Quiberon Bay in 1999 (QB99), 2000 (QB00) and 2001 (QB01), Brest Harbour in 2008 (BR08), Mont-Saint-Michel Bay in 2003, for three batches of oysters aged one year (CA03/1), two years (CA03/2) and three years in 2003 (CA03/3) and Baie-des-Veys in 200203 (BV02-03).

\begin{tabular}{rrrrrrr}
\hline $\begin{array}{l}\text { Regression } \\
\text { parameters }\end{array}$ & AR93 & AR94 & MO07 & QB99 & QB00 & QB01 \\
\hline $\mathbf{R}^{2}$ & 0.805 & 0.939 & 0.875 & 0.850 & 0.939 & 0.959 \\
$(p$-value $)$ & $<0.0001$ & $<0.0001$ & $<0.0001$ & 0.0011 & $<0.0001$ & $<0.0001$ \\
Slope & 1.016 & 0.841 & 1.033 & 1.105 & 1.031 & 0.933 \\
$(p$-value $)$ & 0.9081 & 0.0256 & 0.0068 & 0.5983 & 0.7348 & 0.3538 \\
Intercept & -0.076 & 0.198 & 0.009 & -0.075 & -0.015 & 0.014 \\
$(p$-value $)$ & 0.5899 & 0.0339 & 0.0334 & 0.3340 & 0.7013 & 0.6435 \\
\hline \hline $\begin{array}{r}\text { Regression } \\
\text { parameters }\end{array}$ & BR08 & CA03/1 & CA03/2 & CA03/3 & BV02-03 \\
\hline $\mathbf{R}^{2}$ & 0.923 & 0.951 & 0.872 & 0.919 & 0.928 \\
$(p$-value $)$ & $<0.0001$ & $<0.0001$ & 0.0003 & $<0.0001$ & $<0.0001$ \\
Slope & 1.008 & 0.955 & 0.869 & 1.030 & 1.072 \\
$(p$-value $)$ & 0.9390 & 0.5991 & 0.1445 & 0.7888 & 0.3805 \\
Intercept & -0.155 & 0.113 & 0.192 & -0.093 & -0.111 \\
$(p$-value $)$ & 0.5628 & 0.1280 & 0.3035 & 0.7034 & 0.3690 \\
\hline \hline
\end{tabular}




\section{Figures}

Figure 1. Geographic location of the six oyst er-rearing zones along the Chann el/Atlantic coasts of France at which the oyste r-DEB model was tested: the basins of Arcachon (1-AR) and Marennes-Oléron (2-MO), Quiberon Bay (3-QB), Bre st Harbour (4-BR), Mo nt-SaintMichel Bay (5-CA) and Bei-des-Veys (6-BV). The white stars indicate the oyster-rearing sites and the black stars indicate the location of the hydrological stations. The $20 \mathrm{~km}$ scale applies to the maps showing the six oyster-rearing regions in details.

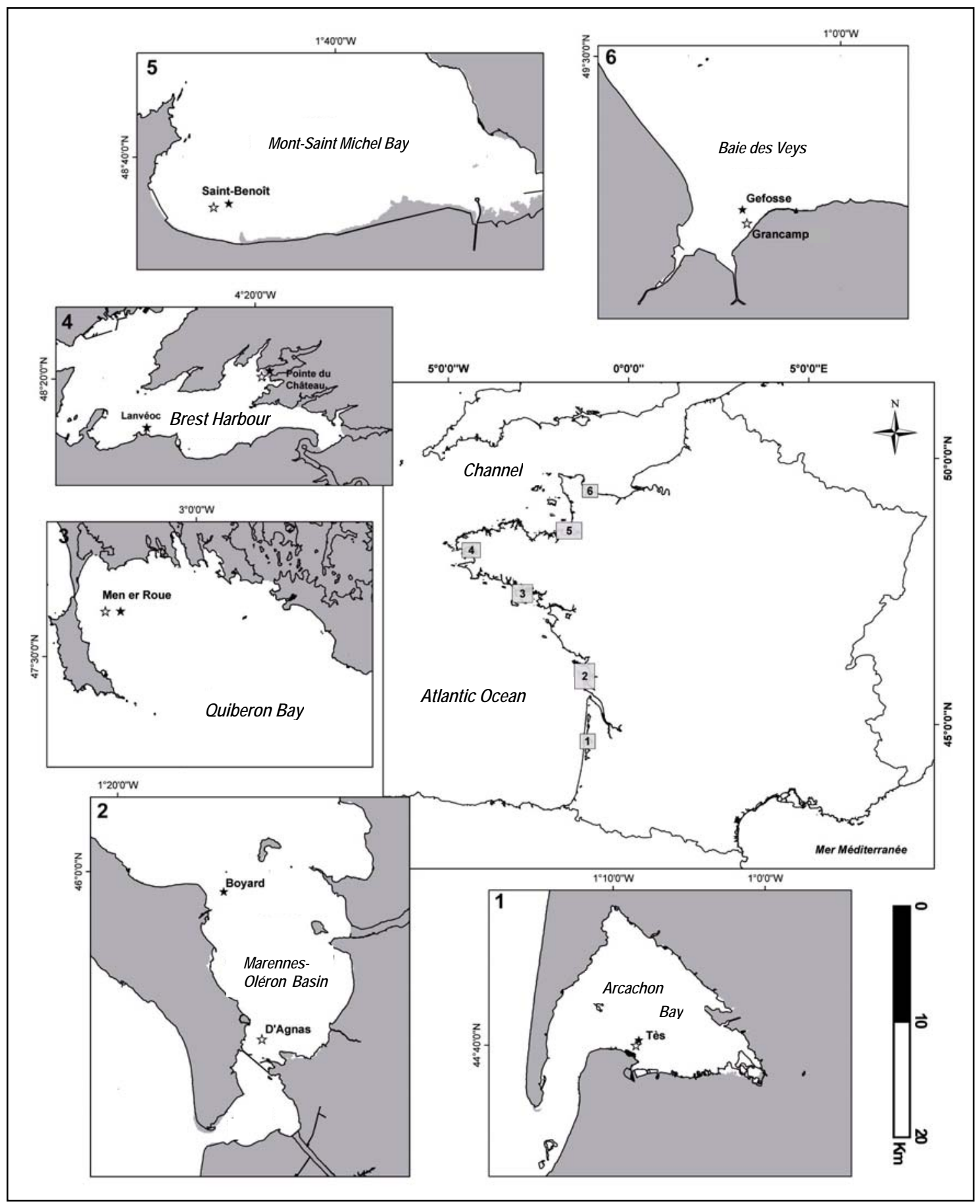


Figure 2. Seawater temperature $\left({ }^{\circ} \mathrm{C}\right.$, grey curve) and phytoplankton concentrations $\left(10^{6}\right.$ cells $\mathrm{L}^{-1}$, black curve), used as forcing variables in the oyster-DEB model in Arcachon Basin (AR) in 1993 and 1994, Marennes-Oléron (MO) in 2007 and Quiberon Bay from 1999 to 2001.

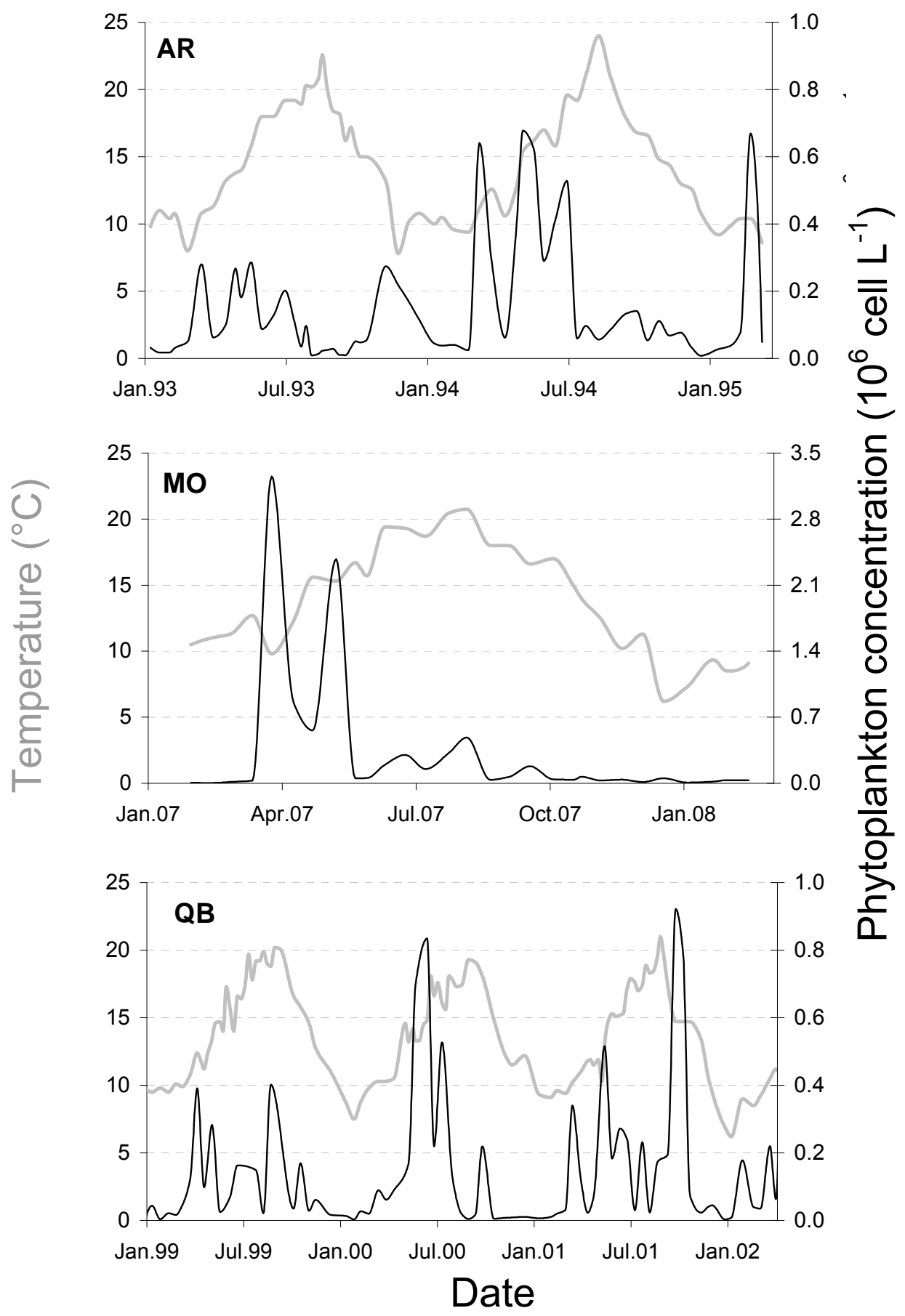


Figure 3. Seawater temperature $\left({ }^{\circ} \mathrm{C}\right.$, grey curve) and phytoplankton concentrations $\left(10^{6}\right.$ cell $\mathrm{L}^{-1}$, black curve), used as forcing variables in the oyster-DEB model in Brest Harbour (BR) in 2008, Mont-Saint-Michel Bay (CA) in 2003) and Baie-des-Veys (BV) in 2002 and 2003.

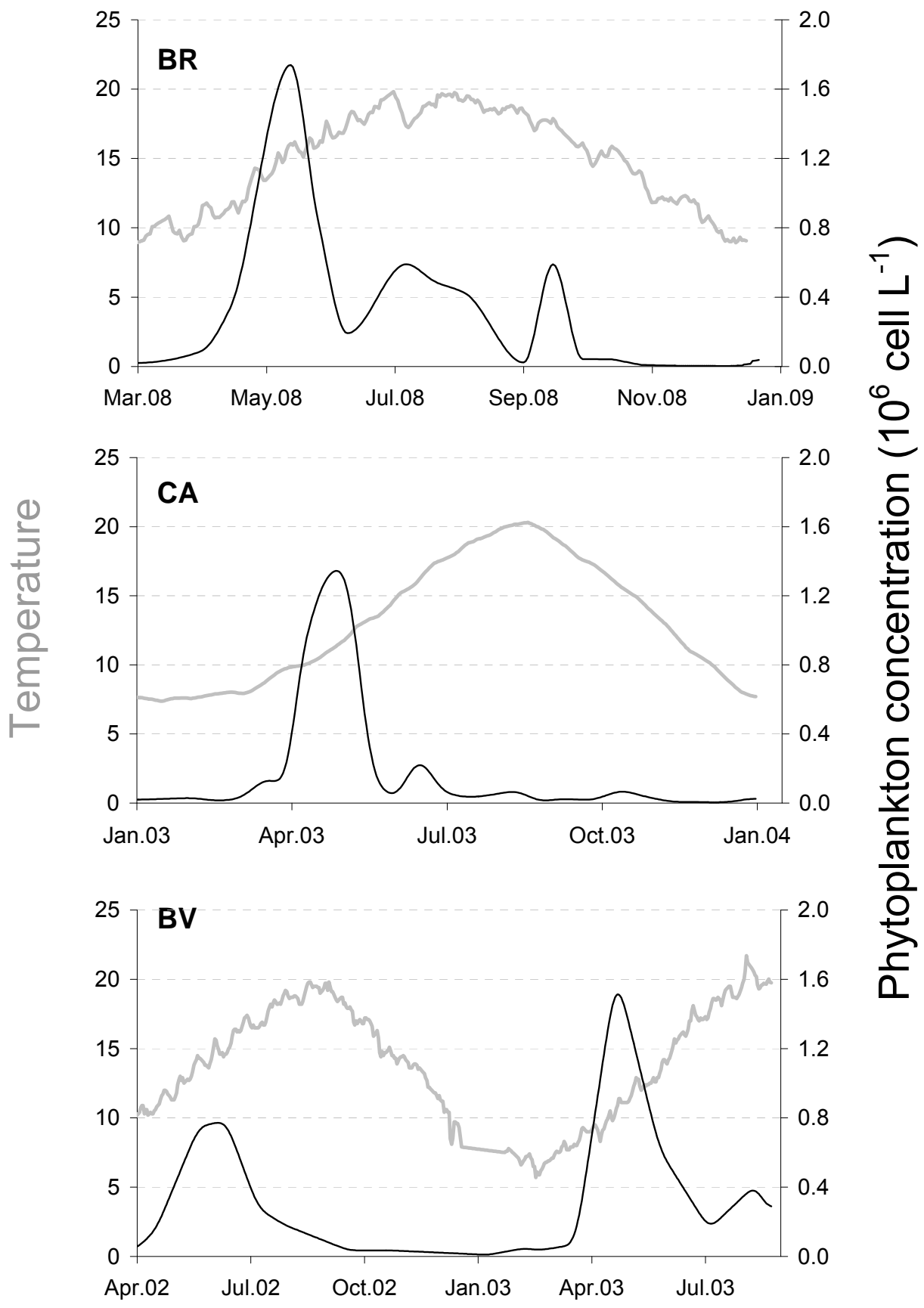

Date 
Figure 4. Observed (black symbols: means with 95\% confidence intervals ( $\mathrm{Cl}$ )) and simulated (grey curve) dry flesh masses in Arcachon Basin in 1993 and 1994 and in the Basin of Marennes-Oléron at the D'Agnas site in 2007. XK is expressed in 103 cell L-1.
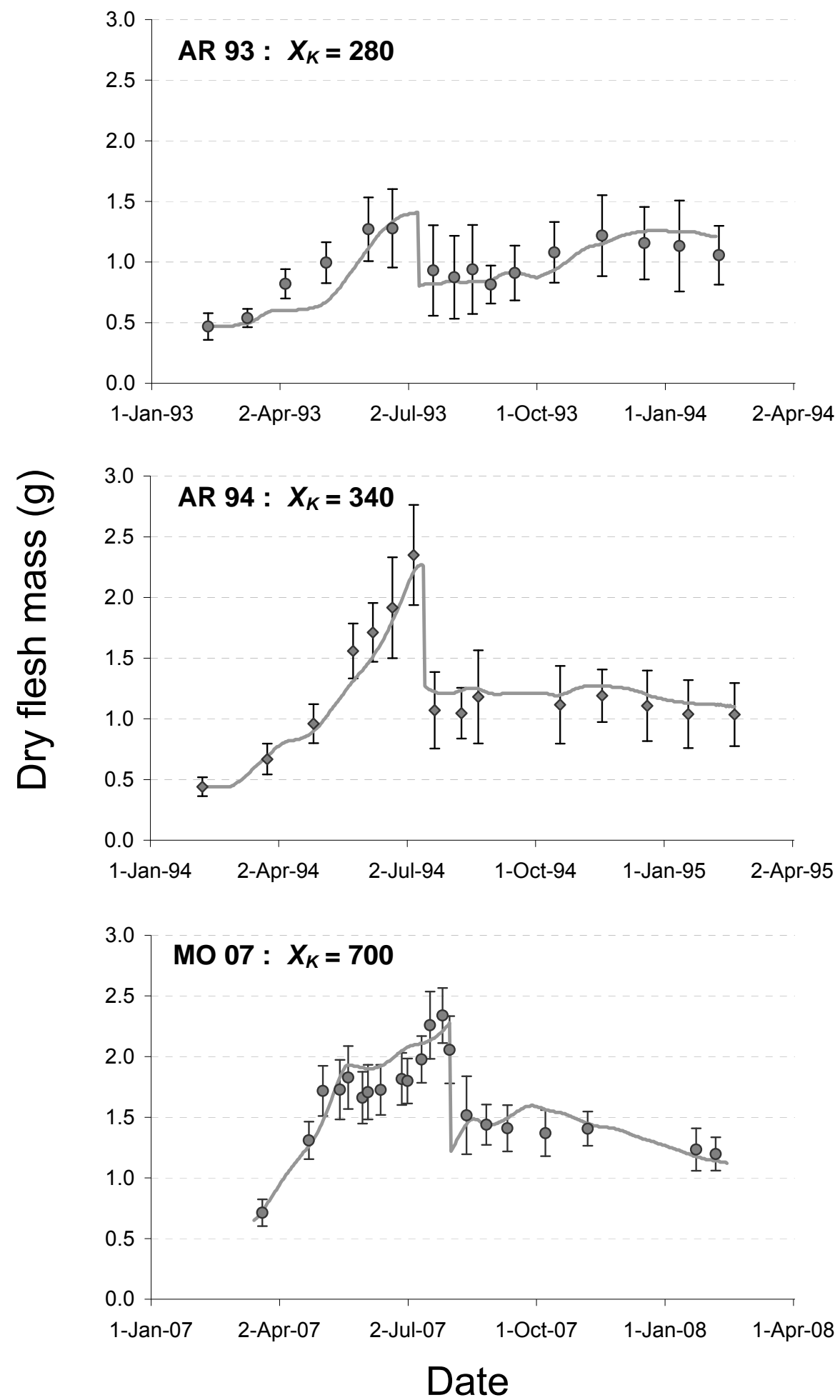
Figure 5. Observed (black symbols: means and 95\% Cl) and simulated (grey curve) dry flesh masses in Quiberon Bay in 1999, 2000 and 2001. XK is expressed in 103 cell L-1.

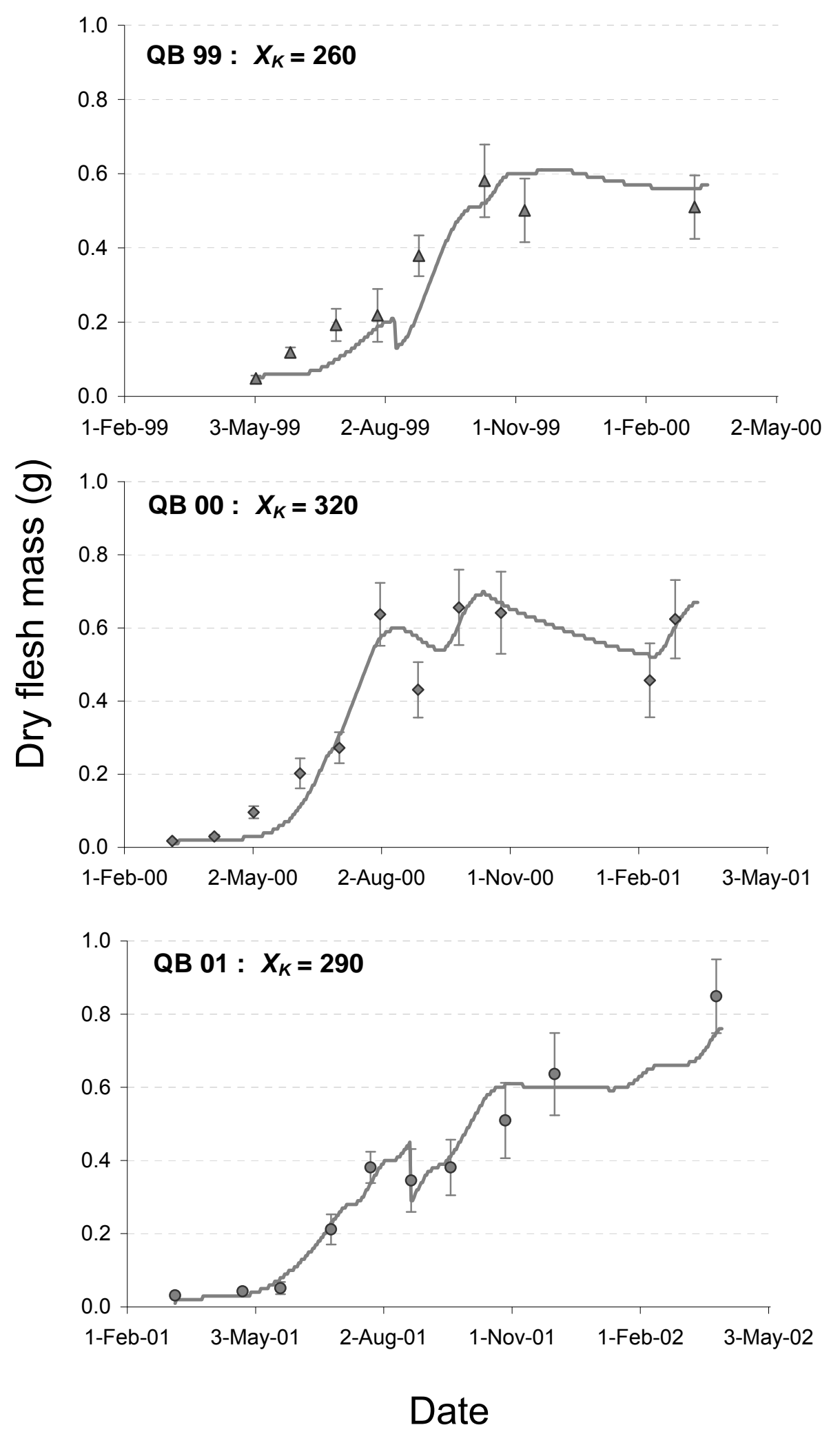


Figure 6. Observed (black symbols: means and 95\% Cl) and simulated (grey curve) dry flesh masses in Brest Harbo ur in 2008, Mont-Saint -Michel Bay in 2003 and Baie-des-Veys in 2002-2003. The three simulations a t Mont-Saint-Michel Bay (CA) corre spond to the three age classes: one year (thin black cu rve), two years (grey curve) and three years (thick bla ck curve). $\mathrm{XK}$ is expressed in 103 cell $\mathrm{L}-1$.
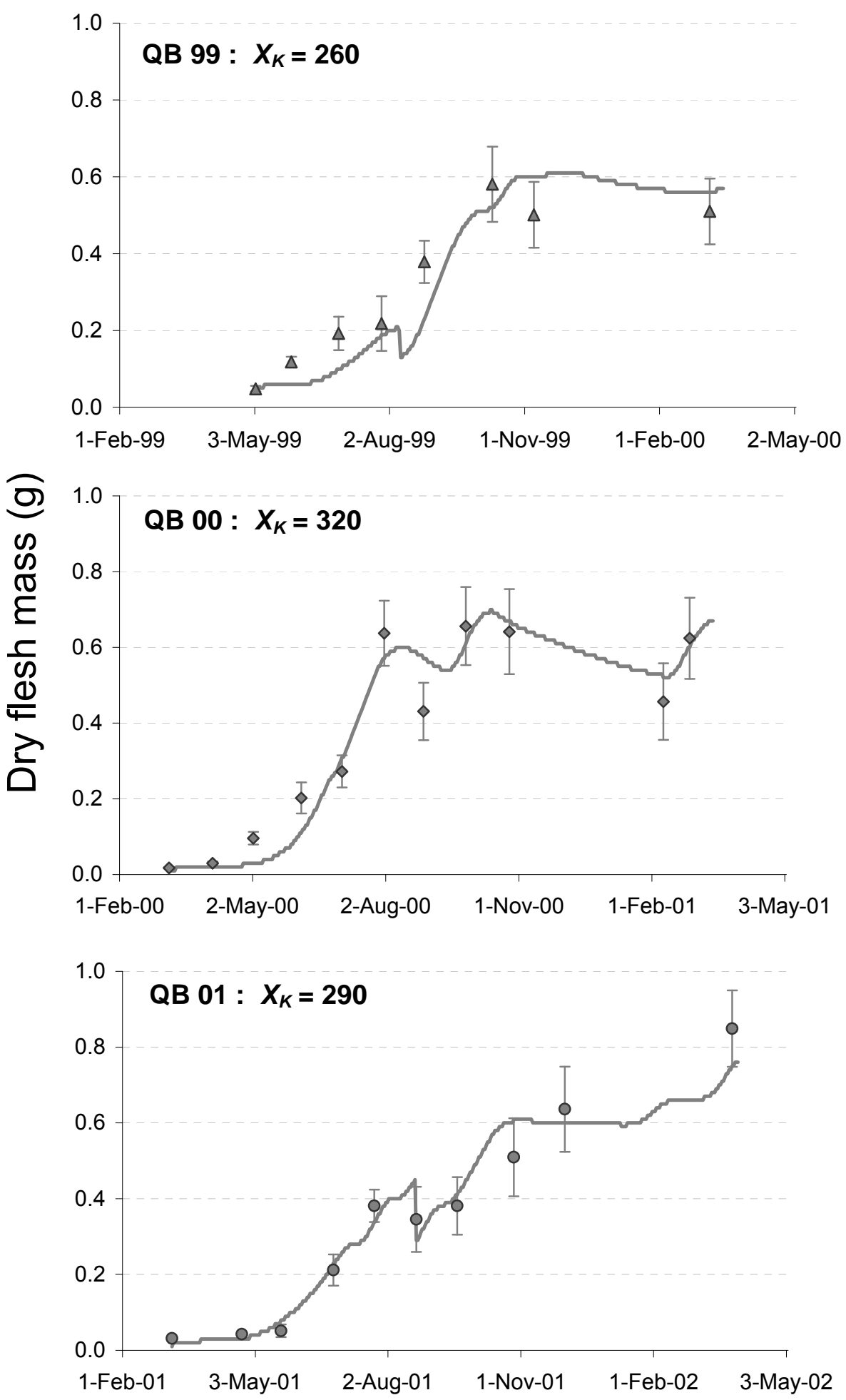

Date 
Figure 7. Linear regression (black line: $X K=1.05 \times$ phyt o]+163.48; $R^{2}=0.77 ; \quad n=11$ ) between mean annual phytoplankton concentr ation and adjusted half -saturation coefficient $\mathrm{XK}$ for the 11 simulations in this study (black dots).

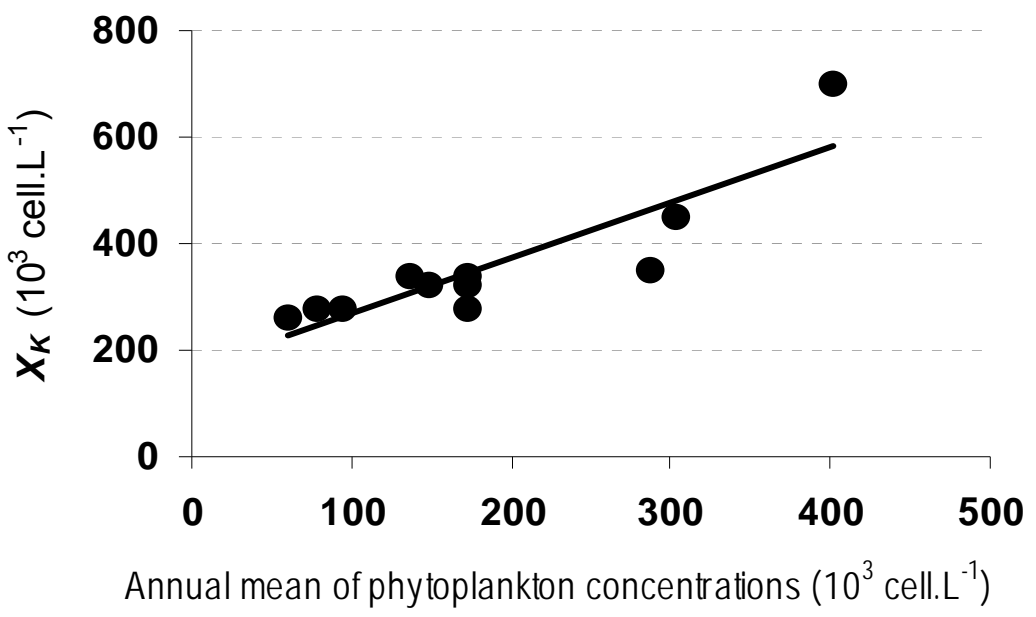

